\title{
CASP7 wt Allele
}

National Cancer Institute

\section{Source}

National Cancer Institute. CASP7 wt Allele. NCI Thesaurus. Code C49559.

Human CASP7 wild-type allele is located within $10 \mathrm{q} 25$ and is approximately $52 \mathrm{~kb}$ in length. This allele, which encodes caspase-7 protein, is involved in apoptosis via the cleavage and activation of both sterol regulatory element binding proteins and poly (ADP-ribose) polymerase (PARP). Overexpression of the CASP7 gene promotes programmed cell death. Loss of heterozyg osity of the CASP7 gene has been detected in several types of solid tumors. 